\title{
COMPARING UNITED STATES AND EUROPEAN UNION APPROACHES TO ENGAGEMENT WITH ASIA
}

\author{
Nguyen Thi Thuy Hang
}

\begin{abstract}
The United States (U.S.) and the European Union (EU) have attempted to project themselves as important actors in Asia. They made official announcements of shifting more attention to Asia in 2011-2012. This paper aims to examine and compare their approaches to engagement with Asia and put forth policy recommendations for them to engage with the region more effectively. As their engagement with Asia is becoming more multidimensional, this paper places an emphasis on security, economics and diplomacy. Drawing mainly on scholarly analysis and official documents regarding the U.S. and EU's engagement with Asia, the paper has found out that there are both similarities and differences in the U.S. and the EU approaches to engagement with Asia. It also highlights the core ideas underpinned the U.S. and the EU's engagement with Asia.
\end{abstract}

Keywords: United States, European Union, engagement, Asia, security

\section{INTRODUCTION}

Since 2011-2012, the United States (U.S.) and the European Union (EU) have announced their policy of increased engagement with Asia. Asia is now firmly positioned on the U.S. and EU's foreign policy agenda. The aim of this paper is threefold: to examine the need for the U.S. and the EU's engagement with Asia, to compare the ways in which the US and the EU have engaged with Asia, and to explore ways in which the U.S. and the EU could have a coherent policy for Asia which would promote their interest in Asia and strengthen their partnership. Acknowledging the broad range of issues in the U.S. and the EU's relations with Asia, this analysis concentrates on three key areas: security, economics and diplomacy. The central argument 
put forth is that there are both differences and similarities in the U.S. and the EU's approaches to engagement with Asia. This study offers evidence of the core ideas underpinned the way the U.S. and the EU engage with Asia. Recommendations are also made for the U.S. and the EU to engage with Asia more effectively.

Towards this end, the paper will begin with a discussion of the needs for the U.S. and EU to expand their engagement with Asia before providing a comparative analysis of U.S. and EU engagement with this region in security, economic and diplomatic areas. In terms of security, the U.S. has implemented an active security engagement with Asia through notable military expansion while the EU has quietly increased its security engagement with the region through sustainable development projects. In terms of economics, both the U.S. and EU have a strong commitment to advancing their economic relations with Asia. In terms of diplomacy, both the U.S. and EU have intensified their diplomatic activities with frequent visits paid by the U.S. and EU high-level officials to Asian nations. The paper goes on to put forth recommendations for the U.S. and the EU to sustain their engagement with Asia. In conclusion, the U.S. and EU will continue to expand their engagement with Asia. If they can draw on their comparative advantages to purse the shared interests and to coordinate their policies to Asia, the U.S. and the EU will be able to magnify their influence on Asian developments.

\section{THE NEED FOR ENGAGING WITH ASIA}

Current dynamics in Asia are shifting global politics, impacting the U.S. and EU's interests, requiring Washington and Brussels to invest more time and energy in the region. Geographically, Asia is the central and eastern part of Eurasia and comprises of about fifty nations. Demographically, Asia is the largest and most populous continent. Almost half of the world's population is in Asia. Economically, Asia is home to many of the world economy's major engines. There has been a shift in global economy from the West to Asia. ${ }^{1}$ From 1995 to 2011, Asia's GDP has increased twice as fast as that of the US and Western Europe. In terms of purchasing power parity, Asia's share of global Gross Domestic Product (GDP) rose to 34 percent in 2009 from 18 percent in $1980 .{ }^{2}$ The region's financial weight has increased 
gradually. Today, Asian stock markets represent 34 percent of market capitalization while the U.S. and Europe account for 33 percent and 27 percent respectively. ${ }^{3}$ In addition, two-thirds of foreign exchange reserves are being held by Asian banks. ${ }^{4}$ Strategically, Asia includes important emerging powers (Russia, China, India and Indonesia). At a time when Asia is seeking to establish a regional security and economic architecture to enhance its stability and prosperity, the U.S. and EU's engagement with Asia is likely to promote their interests in the region. Therefore, since 2011-2012 the U.S. and the EU have pointed out the need for them to pay more attention to Asia.

As for the U.S., increased engagement with Asia is strategically important. The year 2011 marked what has been seen as a crucial shift in U.S. foreign policy agenda. State Secretary Hillary Clinton outlined U.S. "strategic return" to Asia in a foreign policy article entitled "America's Pacific Century." It was the very first official announcement of US rebalancing to Asia. She explained the reasons for the Obama administration to reallocate resources: "to put ourselves in the best position to sustain our leadership, secure our interests, and advance our values." 5 She set forth six lines of action for U.S. "strategic return" to the region: (i) Forging deeper bilateral security alliances; (ii) Intensifying working relations with emerging powers, including with China; (iii) Taking part in regional multilateral institutions; (iv) Enhancing trade and investment; (v) Increasing overall military presence; and (vi) Promoting democratic values and human dignity. ${ }^{6}$ This "strategic return" to Asia was also underlined in President Obama's speech at the Australian Parliament in November 2011. He reaffirmed the need for the US to adapt to this rapidly changing region. He made it clear that U.S. rebalancing to Asia aims to "advance security, prosperity and human dignity across the Asia Pacific."7

Indeed, both State Secretary Clinton and President Obama emphasised economic and strategic calculations in the U.S. rebalance policy to Asia. U.S. increased engagement with Asia is based on the proposition that "the lion's share of the political and economic history of the 21 st century" will be written in the region. ${ }^{8}$ In order to gain substantial benefits from this shift in global geopolitics and sustain its economic growth, the U.S. should expand diplomatic, economic, cultural, development, and security ties with Asia. ${ }^{9}$ 
It should be noted that even the urgent need to concentrate US resources on its domestic issues does not lead to the waning of U.S. engagement in Asia. The severe hardship caused by the global financial crisis and the wars in Iraq and Afghanistan generated a powerful force calling for U.S. retrenchment (greater focus on U.S. domestic issues rather than robust foreign policy endeavours). This seems to be a practical necessity when 79 percent of Republicans and about an equal number of Democrats told pollsters that the U.S. "should pay less attention to problems overseas and concentrate on problems here at home." 10 President Obama once stated: "Now we must invest in America's greatest resource-our people...America, it is time to focus on nation-building here at home." "11 Yet, the Obama administration recognises that US resource constraints should not derail its rebalancing towards Asia, especially at a time when China is "particularly keen on filling the U.S. void in the region in two specific ways: economic clout and hawkish demonstrations in the South China Sea." 12 Any signals of U.S. withdrawing from Asia would pose to its partners and allies in and outside the region profound questions about the long-term viability of the international liberal order, the U.S. economic model, and the U.S. military superiority. Therefore, it is in U.S. interest to reorient its national resources toward Asia. This will endure the U.S.' influence and leadership in the region and the world.

As for the EU, Brussels sees that engagement with Asia is important for the EU's economic growth and political status on global arena. The EU's redirection toward increased engagement with Asia began in 2012; much like the U.S. rebalance policy. ${ }^{13}$ Year 2012 saw a new dynamic of EU engagement in Asia. With its unprecedentedly active participation in Asia's high-level meetings, 2012 was called a "Year of Asia" for the EU. ${ }^{14}$ The EU realises that Asia will become an international focus in the decades to come. Given Asia's vast natural resources, and investment opportunities, it is in Brussels' interest to enhance its relations with the continent. On July 12, 2012, the EU High Representative for Foreign Affairs and Security Policy, Catherine Ashton, in a joint statement with State Secretary Hillary Clinton, underlined that "interdependence between Asia, the United States and the European Union has reached unprecedented levels." 15 The economic interconnectedness between the EU and Asia can be seen in the statistics. China, Taiwan, Japan, Korea and Association of Southeast Asian Nations (ASEAN) represented around $28 \%$ of the 
EU's global trade in goods and services in 2010 and this proportion has continued to increase. ${ }^{16}$ Compared with the EU's trans-Atlantic trade (22.7 percent), the EU's trade with East Asia (27.9 percent is greater. ${ }^{17}$ Especially, China which accounts for 13.9 percent of the EU's total trade has become the EU's second largest trading partner. ${ }^{18}$ The growing economic interdependence between the EU and Asia demonstrates that Asian economy has performed better than many have predicted despite the global economic recession. ${ }^{19}$ Indeed, Asia has played an increasingly important role in driving global growth in the first decade of the 21 st century. The region has offered substantial investment and market opportunities for the EU's firms and businesses. Given Asia's vital importance to the EU's future economic growth, the EU's economic presence in the region should be enhanced.

Besides, the U.S. made the important strategic decision to refocus its foreign policy on Asia and called for its allies outside the region to do the same. This means that the EU, America's most important ally, should support the U.S.' rebalance to Asia by developing its own rebalance policy. It is stated in the 2012 Guidelines on the EU's Foreign and Security Policy that the U.S.' network of bilateral alliances is vitally important to Asian security architecture and that the EU has "a strong interest in partnership and cooperation" to support this network. ${ }^{20}$ Particularly, many of the EU's partners in the region have signalled that they would welcome increased EU engagement which would contribute to Asia's security, sustainable development, wellbeing, and prosperity. For a long time, the EU has desired to have a strong and unified voice in world affairs. Enhanced engagement with Asia seems to be a chance for the EU to foster its political position in international relations. In Catherine Ashton's words, is it is a major strategic objective for the EU to broaden relationship with Asia, simply because "Europe and Asia need each other."21

\section{THE U.S. AND EU SECURITY ENGAGEMENT WITH ASIA: ACTIVE AND QUIET}

Following the official announcement of U.S. rebalance policy to Asia in 2011, there has been an increased U.S. military presence in the region. The deployments of new Littoral Combat Ships (LCSs) in Singapore, and the conclusion of a 10-year pact between the Philippines and the U.S. to increase a larger U.S. military presence in the Philippines are 
the prime examples. Also, in January 2014 the U.S. said that more troops and about 40 M1A2 tanks with other military equipment would be sent to South Korea. ${ }^{22}$ In October 2015, USS Ronald Reagan arrived in Japan at the beginning of a deployment that will foster the capability of the Seventh Feet in Asia. With 5,000 crewmembers and about 80 aircrafts, USS Ronald Reagan is one of the most advanced aircraft carriers of the U.S. Navy. ${ }^{23}$ There will be a deployment of three destroyers by the end of 2015 in Yokosuka (near Tokyo), increasing the number of U.S. warships stationed there to 14, the largest number since the Second World War defeat of Japan in 1945 (Ibid). Moreover, a number of CV-22 Osprey aircrafts will be deployed by the U.S. Air Force at the Yokota Air Base from 2017. ${ }^{24}$

Along with the modernization of the permanent military bases in Asia, the new focus on rotational deployment makes the U.S. military presence in the region become more flexible in structure and more expansive in geography. On 21 August 2015, Pentagon published a new report titled "Asia-Pacific Maritime Security Strategy" which outlined U.S. plans to deploy more ships and warplanes in the region. The U.S. will "maintain the necessary military presence and capabilities to protect U.S. interests and those of allies and partners against potential threats in maritime Asia." ${ }^{25}$ U.S. upgrading of military capabilities in Asia allows the U.S. to conduct military exercises and operations, enhance naval cooperation and open security dialogues with its regional partners. This also helps to ensure security for the U.S.'s Asian allies and strengthen U.S. strategic interests in the region. Yet, Washington's increased military engagement with Asia has been complicated by the reality that Beijing interprets it as containment of China.

As a second-largest economy in the world, China has desired to translate its economic power into political influence. In recent years, Chinese behaviour has become more and more aggressive in the East and South China seas. ${ }^{26}$ For example, in November 2013 China announced an air defence identification zone over the East China Sea. In May 2014, China began drilling activities with the mobile oil rig Haiyang Shiyou 981 near the Paracel Islands in the South China Sea. ${ }^{27}$ In June 2015, China reclaimed 2,900 acres of land across the archipelago of disputed islands in the South China Sea, increasing roughly 50 percent from May 2015 when China reclaimed around 
2,000 acres of land there. ${ }^{28}$ In July 2015, China said that it had every right to drill in the East China Sea close to waters claimed by China and Japan. ${ }^{29}$

Certainly, China knows that there would be negative reactions from its neighbours and the U.S., and Chinese economic growth depends on regional stability and security. However, this does not prevent China from behaving aggressively in the in the East and South China Seas. This can be possibly explained by historical evidence in which certain similarities can be seen between contemporary China and the late-nineteenth-century Germany. It seems that they both have the same strategic ambitions over their regions. Assessing Germany's rise in 1900, Count László Szőgyény-Marich, the Austrian-Hungarian ambassador to Germany, wrote: ${ }^{30}$

The leading German statement...have looked into the distant future and are striving to make Germany's already swiftly growing position as a world power into a dominating one, reckoning here by upon becoming the genial successor to England... People in Berlin are however well aware that Germany would not be in a position today or for a long time to assume this succession... Notwithstanding this, Germany is already preparing with speed and vigor for her self-appointed mission. In this connection, I ...refer to the constant concern for the growth of German naval forces... England is now regarded as the most dangerous enemy which, at least as long as Germany is not sufficiently armed at sea, must be treated with consideration.

We can see some convergences between Germany-England in 1900 and China-U.S. in modern time. Like Germany in 1900, China today has a dream to become not only an economic giant but also a powerhouse in world politics. Former Prime Minister of Singapore, Lee Kuan Yew, once pointed out: "How could [China] not aspire to be number 1 in Asia, and in time the world?." 31 Therefore, it is arguable that the U.S. effort to expand security engagement with Asia is driven to a large extent by a struggle for power and influence in the region. The U.S. put forth that deepening U.S. security ties and alliances in 
Asia aims to deter and defend against threats to the region and the U.S. and resolve disputes peacefully. Implicitly, the security threat that the U.S. has been deeply concerned about in Asia is China's rise. Aaron Friedberg underscored that the U.S. and China are "today locked in a quiet but increasingly intense struggle for power and influence, not only in Asia but around the world." ${ }^{2}$ The struggle for power and influence in Asia between the U.S. and China represents a new kind of great-power competition in which both sides are "trapped in inescapable opposition." ${ }^{33}$

While the U.S. has visibly expanded its security engagement with Asia, the EU has repeatedly spoken and declared about its Asia security engagement but it has played a very limited role in Asian security. The EU has not had a seat at the Asian Defense Minister's Meeting (ADMM) Plus, a platform for ASEAN and its eight Dialogue Partners (the U.S., China, Australia, and five other non-ASEAN states) to enhance security and cooperation for peace, stability, and development in East and Southeast Asia (ADMM 2015). To be excluded from this emerging regional security architecture means that the EU is likely to be disengaged from ADMM's security cooperation mechanisms and dialogues that the U.S. has managed to involve in. At the Shangri La Dialogue 2015, the annual high-level conference on Asian security, the EU High Representative for Foreign Affairs and Security Policy, Federica Mogherini stressed that the EU's “engagement with Asia goes well beyond trade, investment and aid. It is political, it is strategical and it needs to develop more also in the security field." 34

Regarding its security engagement with Asia, Brussels mostly focuses on confidence building measures, exchange of expertise, and common exercises with Asian nations. ${ }^{35}$ Yet, effective security engagement requires visible implementation as the U.S. has done over the past five years in Asia. The EU has a limited role in Asian security because three main reasons. First, the EU's military engagement has been constrained by the principles of the Common Security and Defence Policy (CSDP). Second, the EU' security priorities have been concentrated on humanitarian issues and state-failures. Thus the EU's security engagement in Asia is mostly non-military security cooperation "using financial and economic resources to contribute to peace and stability through the Official and Development Assistance (ODA) and other forms of development and financial aid." 36 For 
instance, in responding to the Typhoon Haiyan which caused massive devastation to the Philippines in November 2013, the European Commission allocated $€ 30$ million in humanitarian assistance and $€ 10$ million for infrastructure reconstruction for the Philippines. ${ }^{37}$ In April 2015, the European Commission provided $€ 300,000$ in humanitarian aid for people displaced by the armed conflict in Central Mindanao in the South of the Philippines. ${ }^{38}$ Last, member states in the EU have formulated and implemented their own national security and defence policies towards Asia which may be competing or even contradicting with the EU's Asian policy. ${ }^{39}$ They place more emphasis on building their national military capabilities than on building the EU's common military capabilities on behalf of 28 EU member states. Lacking necessary military resources, the EU would not be able to transform its security engagement in Asia into a high-profile one like the U.S. has been doing. Head of Asia Department and Senior Research fellow at the Institute for Security and Development Policy (ISDP), Sweden Bernt Berger, pointed out: "For the time being, military involvement is a matter for individual member-states, who most likely would act on their own initiative. Any common EU defence capabilities still need to be developed. The test case will not be in Asia." ${ }^{40}$ Indeed, the EU's non-military security cooperation focussing on technical assistance, development aid, know-how transfer and other non-traditional security has contributed to Asian security and stability. However, this EU-style security engagement in Asia is not improving its political role in the region as the EU's leaders have expected in their announcement of redirections of EU approach to Asia.

The EU and U.S. approaches security engagement in Asia are different. With a strong endeavour to sustain its influence and leadership in Asia, the U.S. has particularly expanded hard-security engagement in the region. By contrast, the EU has strengthened cooperation with Asian nations on non-traditional security issues. It would be impractical for Brussels to try to match Washington in deploying troops, and naval, air forces in Asia as pointed out by Bernt Berger: ${ }^{41}$

...the EU emphasizes the cooperative nature of security engagement in Asia, with a focus on mutual security. The main foci are non-traditional security issues that are inviting for cooperation and that could be a stepping-stone 
for greater diplomatic engagement on hard security issues. Consequently, the EU sees itself as a diplomatic broker on hard security issues and not as a strategic military actor.

A smarter choice for the EU's engagement in Asia is to focus on economic, humanitarian and technical assistance projects. This EU-style security engagement may not draw attraction from the international press, but it is quietly improving stability and well-being of many Asian nations. It is also effectively contributing to promote the EU's interests in Asia. Thus, it is widely agreed that "A more prominent and visible European engagement in Asia 'hard-security' issues could never be as constructive and promoting security as Brussels' 'softsecurity' policies in Asia." ${ }^{42}$

\section{U.S. AND EU ECONOMIC ENGAGEMENT IN ASIA}

Asia has experienced phenomenally economic growth. Its economic dynamism provides the foundation for the prosperity in all nations within the region, and thus for the stability and legitimacy of the national governments region-wide. Asian massive market is significant to the U.S., which is struggling with the consequences of the global financial crisis. Increasing U.S. economic engagement in Asia can be seen in an increasing U.S. trade with Asia between 2008 and mid2015 (Table 1). U.S. trade with Asia has been higher than that with Africa and Europe since 2008. This demonstrates that trading with Asia remains important to the U.S.

Table 1: U.S. Trade with Africa, Europe and Asia from 2008 to mid2015 (US\$ million)

\begin{tabular}{|l|l|l|l|l|l|l|l|l|}
\hline & 2008 & 2009 & 2010 & 2011 & 2012 & 2013 & 2014 & $\begin{array}{l}\text { Mid- } \\
2015\end{array}$ \\
\hline Africa & 141,888 & 86,733 & 113,348 & 125,892 & 99,542 & 85,304 & 72,666 & 26,604 \\
\hline Europe & 760,200 & 589,277 & 667,476 & 778,074 & 785,017 & 787,197 & 824,479 & 166,605 \\
\hline Asia & $1,184,476$ & 951,970 & $1,183,488$ & $1,778,461$ & $1,423,061$ & $1,448,033$ & $1,495,131$ & 718,776 \\
\hline
\end{tabular}

Source: Adapted from the data released by the U.S. Census Bureau, viewed on July 12, 2015, <https://www.census.gov/foreign-trade/balance $\geq$ 
The U.S. commitment to advancing its economic engagement with Asia can be seen clearly in Washington's efforts to further economic engagement with Asian countries. For example, the U.S. has helped to enhance governance and regional connectivity by improving customs procedures across ASEAN countries. ${ }^{43}$ In fiscal years 2009 through 2013, the U.S. provided an assistance of US\$536 million to ASEAN countries to help these countries with drafting laws and regulations, improving public financial management, training government officials, meeting the Word Trade Organization commitments, and enhancing accountability and transparency. ${ }^{44}$ With this assistance, the U.S. helps to improve the ASEAN countries' ability to gain benefits from international trade. In November 2012, the U.S.-ASEAN Expanded Economic Engagement (E3) initiative was launched. The E3 aims to strengthen the ASEAN-U.S. trade and investment tie through expanding trade and investment between the US and ASEAN. In October 2015, the U.S. and 11 partners completed negotiations on the Trans-Pacific Partnership (TPP). The successful conclusion of this landmark trade agreement, which covers over 40 percent global GDP, will serve as a springboard for U.S. expansion of economic relations with Asian nations.

Also, the Obama administration has sought to deepen bilateral trade relations with individual Asian countries. The U.S. and Vietnam started negotiations for a Bilateral Investment Treaty (BIT) in 2008, which was continued with three rounds of negotiations in 2009 and 2010. In 2011, the two countries had various discussions under the Trade and Investment Framework Agreement. In October 2011, the Obama administration obtained Congressional ratification of the U.S.-South Korea Free Trade Agreement (KORUS FTA). Coming into force on 15 March 2012, the KORUS FTA, the second-largest U.S. free trade agreement (next to the North American Free Trade Agreement) has been expected to bring substantial economic benefits to both the U.S. and South Korea. South Korea became the sixthlargest trading partner of the U.S., and the U.S. was the second-largest trading partner of South Korea. ${ }^{45}$ By launching economic initiatives in Asia and entering trade agreements with regional nations, the U.S. not only supports regional economic development and integration thorough capacity building and institutional strengthening but also benefits from Asian massive markets. Importantly, increased economic 
engagement with Asia would contribute to maintaining U.S. influence and leadership in the region.

Like the U.S., the EU has seen huge potential in intensifying economic relations with Asian nations. Moreover, with the approach of promoting trade not dealing with security in its engagement with Asia, the EU has shown greater activism and commitment to economic and trade relations with regional nations. The EU is now one of the leading trading partners of all Asian nations "with an annual average growth rate of trade of 5.8 percent (2008- 2012)." ${ }^{46}$ In 2013, Asia represented 15.3 percent of EU imports ( $€ 678$ billion) and 12.5 percent of exports ( $€ 573$ billion) ${ }^{47}$ Among the top ten trading partners of the EU (2013) are three Asian nations, China, Japan and South Korea which accounted for 17.9 percent of the EU's total trade: China 12.5 percent, Japan 3.2 percent, South Korea 2.2 percent. ${ }^{48}$ For ASEAN, the EU accounted for 13.1 percent of ASEAN's total trade in 2012.49 Furthermore, the EU is one of the most important investors in Asia. In 2012, 21.4 percent (or $€ 57$ billion) of EU's outward investment flowed into Asia. ${ }^{50}$ In order to advance its economic engagement with Asia, the EU continues negotiations on trade and investment with regional nations. For example, the EU is now negotiating the Free Trade or Comprehensive Economic Partnership Agreement (CEPA) with India, Japan, Malaysia, Thailand, and Vietnam. The EU is also negotiating the Partnership and Cooperation or Framework Agreements with Afghanistan, Australia, Brunei, China, Japan, Malaysia, and New Zealand. ${ }^{51}$ Clearly, trade and investment relations with regional nations are one of the EU's top priorities in engagement with Asia. ${ }^{52}$

All in all, trade and investment form the backbone of the EU's economic engagement with Asia. In spite of the fact that both the EU and Asia have been adversely affected by the global economic recession of 2008 and the Eurozone crisis, their trade ties have been intensified over the time and their economies have become further interconnected. ${ }^{53}$ Increased economic presence in Asia can, to a great extent, helps the EU to recover from the Eurozone crisis. It is expected that Asia will continue to take the lead in the global economic recovery. ${ }^{54}$ Thus, the EU has made stronger efforts in negotiating free trade agreements with Asian nations which had been, in the EU's view the hurdle to economic liberalisation. The EU's increased visibility in Asian economies and its endeavour to take a more active role in 
world affairs led to expectations that the EU's economic engagement will offer answers to the fundamental questions of the EU's global significance. Like the U.S., the EU has shown that increasing economic engagement with Asia seems to be a smart and practical choice for them to benefit from Asia, the fastest-growing region in international trade. Also, increased economic engagement is arguably a key means for the U.S. and the EU to translate their economic power into political influence in Asia.

\section{THE U.S. AND EU DIPLOMATIC ENGAGEMENT WITH ASIA}

In terms of diplomacy, the Obama administration has shown that U.S. high-level diplomatic activities need to be strengthened as an important component of US rebalancing. President Obama visited Asia six times by far. In his sixth trip to this region, President Obama travelled to Beijing, China for the APEC Leaders Meeting, to Nay Pyi Taw and Yangon, Myanmar, for the East Asia Summit and US-ASEAN Summit; and to Brisbane, Australia for the G20. ${ }^{55}$ The U.S. State Secretary, Hillary Clinton, travelled to Asia fourteen times, visiting almost all nations across the Asia-Pacific and all ASEAN member states. The U.S. Secretaries of Defense, Robert Gates and Leon Panetta, visited Asia thirteen times during the first Obama administration. National Security Advisor Thomas Donilon, Chairmen of the Joint Chiefs of Staff Admiral Michael Mullen and General Martin Dempsey, and several chiefs of the U.S. military services also had regular visits to Asian countries. Apart from sending senior officials to various regional meetings in Asia, in 2009 President Obama appointed the first U.S. Ambassador for ASEAN Affairs and in 2011 he appointed the first resident U.S. Ambassador to ASEAN. ${ }^{56}$ The U.S. regular participation in key regional meetings (East Asia Summit, ASEAN Regional Forum meeting), and increased involvement in regional institutions (signing the ASEAN Treaty of Amity and Cooperation) illustrate that U.S. diplomatic engagement with Asia gives a high priority to multilateralism and regionalism. ${ }^{57}$ This helps to reverse the perception that U.S. leaders seem to ignore Asia as they are not frequent visitors to the region. ${ }^{58}$

In the same approach as the U.S. to Asia, the EU has made progress in intensifying its diplomatic activities in Asia. The frequent visits paid by the EU's high-level officials to Asian nations are making 
headlines in international press. The EU's diplomatic focus on Asia is certainly beneficial to its overall engagement with Asia. In May 2015 High Representative of the EU Foreign Affairs and Security Policy, Federica Mogherini, travelled to South Korea and China and these were her first visit to Asia. She also travelled to Japan for the EU-Japan summit, to Singapore for Shangri-La Dialogue 2015 and to Malaysia for the ASEAN Regional Forum. Her frequent visits to Asian nations illustrate the growing significance of Asia in the EU's agenda. Mogherini highlighted this in her speech at 2015 ShangriLa Dialogue: "It is not by chance that I have personally travelled to the region twice in less than one month, and in the very beginning of my mandate." ${ }^{59}$ The EU' leaders are intensively preoccupied with such political issues as Ukraine, migration crisis, Syria civil war, and Israeli-Palestinian violence. ${ }^{60}$ Yet, this has not diminished the EU's high-profile engagement with Asia. Indeed, Asia has been permanently positioned in the EU's foreign policy agenda: "As while the EU continues to be deeply engaged IN Asia, we want to be more and more engaged WITH Asia, to address together our common challenges, and to take full advantage of our common opportunities." 61 These EU's diplomatic interactions with Asia will be certainly beneficial for the EU-Asia relations.

\section{SUSTAINED ENGAGEMENT: POLICY RECOMMENDATIONS}

The U.S. and EU's increased engagement with Asia in security, economic and diplomatic areas since 2011-2012 underline Asian importance in the U.S. and EU's global agenda. The U.S. and EU have different focal points in their approaches towards Asia. Regarding security, the U.S. focuses on strengthening military alliances in the region and aims to keep China in check. By contrast, the EU tends to promote non-military security cooperation, thus it places more focus on humanitarian assistance, development aid, technology transfer and other non-traditional security which in the EU's perspective will make contribution to Asian security and stability. While the U.S. has implemented a high-profile security engagement with Asia through visible military expansion, the EU has quietly increased its security engagement with the region through sustainable development projects. Thus, the U.S. security engagement with Asia has been perceived by China as an expression of Washington's hegemonic ambitions and containment of China's rise. The EU's security engagement has not 
caused ambivalence between the EU and any particular country in Asia. China and other Asian nations see the EU-style security engagement as a window of development opportunities for both the EU and Asian nations. The chief operating officer of the European External Action Service, David O'Sullivan asserted this, "It is true that we as the EU don't have a leading role on hard security issues given the absence of major military assets or bases in the region." ${ }^{2}$ According to him, the lack of military dimension in the EU's engagement with Asia can be an advantage: "We are seen as engaged, but not threatening; active but without a geo-political agenda." ${ }^{63}$ This was also echoed by Parello-Plesner: ${ }^{64}$

The lack of a substantial military presence in the AsiaPacific grants the EU greater freedom of maneuver to pursue this type of trade strategy without criticism about containment from China. This is not the case for the United States, which China frequently accuses of a military and economic policy of containment

In economic and diplomatic engagement with Asia, the U.S. and the EU hold the same view. As the world economies have been intertwined and the global economic engine is shifting to Asia, it is crucially important for Washington and Brussels to enhance economic and diplomatic interactions with Asian nations. Thus the U.S. and EU have deeply involved in economic projects and diplomatic activities with Asia. Their attempts have actually created more trade and commercial opportunities for Asian people and the U.S. and the EU's peoples. The U.S. and EU's economic influence is perceivable in Asia as the regional nations have concluded major free trade deals with the U.S. and the EU.

The U.S. and the EU have been close allies and they should remain close in engagement with Asia. Their engagement approaches to Asia should be complementary rather than alternative or competing. This will help to promote their mutual benefits and ultimately strengthen their alliance. Furthermore, when the U.S. and the EU have a complementary approach to Asia, they are more likely to contribute to Asian security and prosperity. This requires the U.S. and EU to have more consultations and coordination in their engagement approaches to Asia. Therefore, the U.S. and EU "decided to continue the regular 
high level U.S.-EU dialogue on the region at the political and senior officials' level." ${ }^{65}$

Following recommendations should be implemented by the U.S. and the EU to avoid damaging their partnership and to increase the effectiveness of their engagement with Asia.

\section{For the EU}

- Focusing on trade: The EU engagement with Asia should be mainly about increased trade and investment which will bring deeper social and political changes. The EU should intensify its economic and financial relations with Asian nations and seek to complete negotiations on free trade with them. The EU's increased investment in Asia will bring more opportunities for the EU's businesses to expand into the region and explore potential new trade partners. This will contribute considerably to the EU's economic growth.

- Enhancing non-traditional security cooperation: The EU should pay more attention to the key non-traditional security threats facing both the EU and Asia, namely climate change, energy security, and sustainability which have been worsening by the unexpected consequences of rapid industrialisation and economic growth. Both the EU and Asia are contributing much to the atmospheric pollution, thus they have a lot to share in dealing with climate change. By organising training workshops and working groups the EU and Asia can offer each other examples, experience and expertise in coping with climate change impacts and developing low-carbon economies.

- Avoiding confrontation: The EU should avoid taking side with a particular Asian nation in the territorial claims in the South and East China Seas. The EU's engagement with Asia should be seen as a super-partner not as another superpower. Because the disputes in the South and East China Seas can pose certain threats to the EU's interest in the region, the EU should actively advocate solving the disputes through bilateral and multilateral negotiations. This does not mean that the EU has no confidence and leadership ambition on the global agenda. Arguably, Asia is 
not the right place for the EU to show its global ambitions. The very first priority of the EU's engagement in this region now is to maximise economic benefits, not to secure a geopolitical role.

- Comprehensive engagement with ASEAN: The EU engagement with ASEAN should be based on common economic and political interests. With its experience in regional integration, the EU will offer a prime example for ASEAN to follow. It should be reiterated that economic integration would gradually lead to political integration. ${ }^{66}$ Thus, in the years ahead, the EU's engagement with ASEAN should aim to achieve five objectives: (i) to further open regional market for goods and services, (ii) to enhance transparency in government procurement, (iii) to provide ASEAN more assistance in regional integration, (iv) to raise the regional awareness of sustainable development, and (v) to promote democracy and human rights and consolidate the rule of laws.

- mart engagement with China: China is a significant nation in the rapidly changing Asian geo-political landscape. China is also has close linkages with all major international issues and actors in Asia. Thus, it is crucial for Brussels to foster its relations with Beijing. The EU's engagement with China should be based on mutual economic, political and cultural interests. The EU should avoid taking position on China's critical internal issues namely Taiwan and Tibet. The EU's relationship with China can be deepened through increasing economic interdependence and complementarity. ${ }^{67}$ In order to smartly engage with China, it is crucial for the EU to increase its understanding of Chinese market and Chinese way of conducting business. Knowledge deficit in Chinese bureaucracy, political culture and legal conceptions will produce unintended consequences in the EU's engagement with China particularly and Asia generally.

\section{For the U.S.}

- $\quad$ Dealing with resource constraints: U.S. engagement with Asia has steadily expanded and concentrated on all three military, economic and diplomatic areas. Strengthening its domestic 
power is crucial for the U.S. to successfully engage with Asia. Thus, the U.S. needs to deal with resource constraints by (i) increasing efficiency in production, renewing labour force, promoting technological innovation, and accelerating federal revenue, (ii) maintaining its space, air, and naval forces superiority, and (iii) reducing political polarization to make it easier for the U.S. government to address the nation's most important economic and security questions.

- $\quad$ Strengthening economic linkages: The U.S. must encourage free trade agreements with Asian nations without political prejudices. Besides, protectionism policy is necessary to protect domestic businesses but it should not be used as political tools to restrain trade between the U.S. and other Asian nations. The major aim of broadening and deepening U.S. trade relations with Asia is to accelerate U.S. economic interconnectedness with the region. The U.S. should ensure that its increased economic engagement with Asia will open up new opportunities of commerce in the region.

- $\quad$ Reinforcing alliances and partnerships: The U.S. alliances and partnerships in Asia are important in its engagement with the region. The U.S. needs to enhance its capacity to protect its alliance partners while asking them to make a proper contribution to regional security. Also, the U.S. needs to consolidate its old and emerging partnerships in the region by deepening economic, diplomatic and security ties with these partners.

- $\quad$ Pragmatic engagement with China: Many Asian nations depend on their trade ties with China. Revenue from trade relations with China contributes considerably to their economic growth and they do not want to choose between the U.S. and China. Thus, the U.S. needs to balance these two dynamics by practically engaging with China. Washington must pursue its engagement with Asia, but to make this pursuit perceived by Beijing as a containment of China would be a colossal mistake. A China, relatively stable and cooperative, is more in US interests. In order to deepen its engagement with China, the U.S. should build effective relationship with China by (i) coordinating with China in developing regional mechanisms for regional activities. The 
U.S. and Chinese coordination in development assistance and disaster relief would serve as a springboard for their cooperation in other areas; (ii) participating in more effective high-level dialogues with China to build trust and increase cooperation; and (iii) playing an active role in solving peacefully the disputes in the South and East China Seas, North Korea's nuclear program which have been the source of mutual doubts and suspicions about Washington and Beijing's future intentions.

- $\quad$ Continuing democracy promotion: The U.S. should continue its democracy promotion in Asia through engagement with the region. Helping to improve the lives of Asian peoples greatly matters to the U.S. because in the world of increasing interdependence the U.S. cannot remained detached from the events outside its borders. Widespread misery in Asia may cause political disorder, socio-economic instability, refugee crisis, and environmental degradation that will affect the U.S. Supporting the spread of democracy helps to advance the well-being of Asian peoples and serve U.S. interests. President Clinton strongly asserted the peaceful nature of democracies "democratic states are less likely to threaten our interests and more likely to cooperate with the U.S. to meet security threats and promote free trade" $" 68$.

\section{CONCLUSION}

It has been shown that there are both similarities and differences in the U.S. and the EU approaches to engagement with Asia. On the whole, it can be argued that they have similar approaches, with some slight differences. First, both the U.S. and the EU see the need for them to shift more attention to Asia. Increased engagement with Asia has been considered as a core element of U.S. national security strategy and a major strategic objective of EU foreign policy. Second, with regard to the implementation of engagement, the U.S. and the EU have comprehensively engaged with multiple aspects, comprising security, economics, and diplomacy. While the U.S. and the EU share the same approach in economic and diplomatic engagement with Asia, they have differences in security dimension of engagement with this region. The U.S. has such a high-profile military expansion in the region that the 
EU cannot match with. The EU remains quiet and detached with the hard-military security issues but active in the non-traditional security cooperation. The EU's main argument for this is that by focussing on such issues as humanitarian assistance, development aid, technology, and technical transfer, the EU will improve the well-being of the Asian peoples and advance peace and stability in the region. The U.S. wants to increase its geopolitical and strategic influence in the region, thus it has visibly expanded its troops, air forces and naval forces in Asia. It has been suggested in this article that the U.S. and EU engagement with Asia should be increased in the years ahead. The U.S. and the EU have common interests and values in the region. Henceforth, they should draw on their comparative advantages to purse the shared interests and coordinate their policies to Asia. If they can act together the, the U.S. and the EU are magnifying their influence on Asian developments and ultimately achieving together in that part of the world.

\section{NOTES}

1 Marie J Chenard and Westad, Arne O. Westad, "The EU's Engagement with Asia," Global Policy, Vol. 5, Supplement 1, 2014, <http://onlinelibrary. wiley.com/doi/10.1111/1758-5899.12151/pdf>

2 Ibid.

3 Ibid.

4 Gareth Price, Asia and Europe: Engaging for a Post-crisis World, London: Chatham House, Asia Programme Paper ASP PP 2011/01, January 2011, $<$ http://www.chathamhouse.org/sites/default/files/public/Research/ Asia/0111price_pp.pdf>, p. 7.

5 Hillary Clinton, “America's Pacific Century," Foreign Policy, 11 October 2011, <http://foreignpolicy.com/2011/10/11/americas-pacific-century/> 6 Ibid.

7 Barrack Obama, "Remarks by President Obama to the Australian Parliament," Washington, DC: The White House, 17 November 2011, $<$ https://www.whitehouse.gov/the-press-office/2011/11/17/remarkspresident-obama-australian-parliament>

8 Kurt Campbell and Brian Andrews, Explaining the US 'Pivot' to Asia, London: Chatham House, Americas 2013/01, August 2013, <https:// www.chathamhouse.org/sites/files/chathamhouse/public/Research/ Americas/0813pp_pivottoasia.pdf>, p. 2. 
9 See "Remarks by National Security Advisor Tom Donilon," Washington, DC: The White House, 15 November 2012, <https://www.whitehouse. gov/the-press-office/2012/11/15/remarks-national-security-advisor-tomdonilon-prepared-delivery>; Susan Rice, "America's Future in Asia," Washington, DC: The White House, 21 November 2013, <https://www. whitehouse.gov/the-press-office/2013/11/21/remarks-prepared-deliverynational-security-advisor-susan-e-rice>; The White House, "The Fact Sheet: The East Asia-Pacific Rebalance: Expanding U.S. Engagement," 2013, <http://www.state.gov/r/pa/pl/2013/218776.htm>; "Remarks By President Obama At the University Of Queensland," Washington, DC: The White House, 15 November 2014, <https:/www.whitehouse.gov/the-pressoffice/2014/11/15/remarks-president-obama-university-queensland $>$; and The White House, "The Fact Sheet: The Fiscal Year 2014 Federal Budget and the Asia Pacific," Washington, DC: The White House, 2014, <http:// www.whitehouse.gov/sites/default/files/docs/asia_pacific_rebalance_ factsheet_20130412.pdf>

10 Stephen Sestanovich, Maximalist: American in the World from Truman to Obama, New York: Alfred A. Knopf, 2014, p. 302.

11 "Remarks by the President on the Way Forward in Afghanistan," Washington, DC: The White House, 22 June 2011, <https://www.whitehouse. gov/the-press-office/2011/06/22/remarks-president-way-forwardafghanistan>

12 Karam Singh Sethi, "The U.S. Needs a Refocused Rebalance," The Diplomat, 26 March 2015, <http://thediplomat.com/2015/03/the-u-s-needsa-refocused-rebalance/ $>$

13 The European External Action Service, "The EU in Asia," Brussels: The European Union, 2012, http://eeas.europa.eu/asia/docs/2012_eu_in_asia year_facts_figures_en.pdf $>$

14 Ibid.

15 "US-EU Statement on the Asia-Pacific Region." Washington, DC: U.S. Department of State, July 2012, <http://www.state.gov/r/pa/prs/ ps/2012/07/194896.htm>

16 The Council of the European Union, "Guidelines on the EU's Foreign and Security Policy in East Asia," Brussels: The European Union, 15 June 2012, <http://www.diplomaticourier.com/wp-content/uploads/2014/08/eeas. europa.eu_asia_docs_guidelines_eu_foreign_sec_pol_east_asia_en.pdf $>$ 17 Ibid.

18 Ibid. 
19 Ibid.

20 Ibid.

21 The European External Action Service, "The EU in Asia," Brussels: The European Union, 2012, <http://eeas.europa.eu/asia/docs/2012_eu_in_asia_ year_facts_figures_en.pdf $>$

22 "US to Boost Military Presence in South Korea," Russia Today, 8 January 2014, <https:/www.rt.com/news/us-south-korea-military-296/>

23 Koji Udeda, "Carrier USS Ronald Reagan Arrives in Japan," The Associated Press, 1 October 2015, <http://www.navytimes.com/story/ military/2015/10/01/carrier-uss-ronald-reagan-arrives-japan/73149368/> 24 "Controversial US Planes to be Deployed in Tokyo despite Local Opposition," Russia Today, 12 May 2015, <https://www.rt.com/ news/257777-osprey-plane-japan-usa/>

25 U.S. Department of Defense. 2015. "Asia-Pacific Maritime Security Strategy." Accessed December 2015 < http://www.defense.gov/Portals/1/ Documents/pubs/NDAA\%20A-P_Maritime_SecuritY_Strategy-081420151300-FINALFORMAT.PDF $>$

26 Yuan Sun, Maritime Territorial Disputes Involving China, New York: Nova, 2013.

27 Lowy Institute. 2015. "South China Sea: Conflicting Claims and Tensions." 2015, <http://www.lowyinstitute.org/issues/south-china-sea>

28 Mark Hanrahan, "South China Sea Dispute: Pentagon Report Says China Massively Stepped up Land Reclamation on Disputed Islands," International Business Times, 21 August 2015, <http:/www.ibtimes.com/ south-china-sea-dispute-pentagon-report-says-china-massively-steppedhland-reclamation-2063013>

29 Ben Blanchard, "China: We Have Every Right to Drill in the East China Sea." Business Insider, 24 July 2015, <http://www.businessinsider.com.au/ china-we-have-every-right-to-drill-in-the-east-china-sea-2015-7>

30 Paul M. Kennedy, The Rise of the Anglo-German Antagonism: 18601914, New York: Humility Books, 1980, p. 241.

31 Graham Allison, Robert D. Blackwill and Ali Wyne, Lee Kuan Yew: The Grand Master's Insights on China, the United States, and the World, Cambridge: MIT Press, 2013, p. 2.

32 Aaron L Freidberg, A Contest for Supremacy: China, America, and the Struggle for Mastery in Asia, New York: W. W. Norton \& Co., 2011, p. 1. 
33 Ashley J. Tellis, Balancing without Containment: An American Strategy for Managing China, Washington, DC: Carnegie Endowment for International Peace, 2014, p. 2.

34 Federica Mogherini, "Speech by High Representative/Vice-President Federica Mogherini at the IISS Shangri-La," 2015, <http://eeas.europa.eu/ statements-eeas/2015/150531_02_en.htm>

35 Ibid.

36 Gustaaf Geeraerts and Eva Gross (eds.), Perspectives for a European Security Strategy towards Asia: Views from Asia, Brussels: Brussels University Press, 2011, p. 120.

37 The European Commission, "Humanitarian Aid and Civil Protection: The Philippines, 2015, <http:/ec.europa.eu/echo/where/asia-and-oceania/ philippines_en>

38 Ibid.

39 Geeraerts and Gross (eds.), Perspectives for a European Security Strategy towards Asia, p. 115.

40 Bernt Berger, "The EU and Asian Security: What Role Does the EU have in East Asia Security?," The Diplomat, 28 June 2015, <http://thediplomat. com/2015/06/the-eu-and-asian-security/>

41 Ibid.

42 Geeraerts and Gross (eds.), Perspectives for a European Security Strategy towards Asia, p. 114.

43 GAO, "Southeast Asia Trends in US and Chinese Engagement," 2015, $<$ http://www.gao.gov/assets/680/672245.pdf>, p. 50.

44 Ibid., p. 51.

45 Williams Brock, Manyin Mark, Jurenas Remmy and Patzer Micheala, The U.S.-South Korea Free Trade Agreement (KORUS FTA): Provisions and Implementation, Washington, DC: Congressional Research Service, 2014, $<$ https://fas.org/sgp/crs/row/RL34330.pdf>, p. 5.

46 The European External Action Service, "EU-Asia Fact Sheet," 2014, $<$ http://eeas.europa.eu/factsheets/docs/20140714_factsheet_eu-asia_en.pdf $>$ 47 Ibid.

48 Ibid.

49 Ibid.

50 Ibid.

51 Ibid. 
52 Jon Moran, "The EU and Asia in a Changing Global Order," in Geeraerts and Gross (eds.), Perspectives for a European Security Strategy Towards Asia.

53 Andrew Chiu and Peter MacKay, "The Growing Financial Interdependence between Europe and Asia," in Lars Oxelheim (ed.). EU-Asia and the RePolarization of the Global Economic Arena, Singapore: World Scientific Publishing Co., 2012, pp. 125-154.

54 Yumiko Okamoto, "Japan's Role on the New Economic Map: What is Japan's New Identity in the 21st Century," in Oxelheim (ed.), EU-Asia and the Re-Polarization of the Global Economic Arena.

55 The White House, "The Fact Sheet: The Fiscal Year 2014 Federal Budget and the Asia Pacific," 2014, <http://www.whitehouse.gov/sites/default/files/ docs/asia_pacific_rebalance_factsheet_20130412.pdf $>$

56 Mark Hanrahan, "South China Sea Dispute: Pentagon Report Says China Massively Stepped up Land Reclamation on Disputed Islands," 2015, <http:// www.ibtimes.com/south-china-sea-dispute-pentagon-report-says-chinamassively-steppedh-land-reclamation-2063013>

57 U. S. State Department, "East Asian and Pacific Affairs: Official Travel to the Region," 2015, <http://www.state.gov/p/eap/trvl/index.htm>

58 David Shambaugh, "Assessing the US "Pivot" to Asia," 2013, <http:// www.isn.ethz.ch/Digital-Library/Publications/Detail/?lang=en\&id=165271> (accessed August 2015).

59 Mogherini, "Speech by High Representative/Vice-President Federica Mogherini at the IISS Shangri-La," 2015.

60 Euobserver News, 2015, <https://euobserver.com/foreign> (accessed October 2015).

61 Mogherini, "Speech by High Representative/Vice-President Federica Mogherini at the IISS Shangri-La," 2015.

62 David O'Sullivan, "Priorities for EU Diplomacy in East Asia," 12 February 2013, <http://eeas.europa.eu/asia/docs/20130205_grips_speech_ final_en.pdf>

63 Ibid.

64 Jonas Parello-Plesner, "What is Europe's role in Asia-Pacific?," Asia Pacific Bulletin, 203, 2013, <http://www.eastwestcenter.org/publications/ grading-europe-in-the-asiapacific-european-foreign-policy-scorecard-2013> 65 "US-EU Statement on the Asia-Pacific Region," Washington, DC: U.S. Department of State, 12 July 2012, <http://www.state.gov/r/pa/prs/ ps/2012/07/194896.htm> 
${ }^{66}$ Ali El-Agraa, "A History of European Integration," in Ali El-Agraa (ed.), The European Union: Economic and Policies (8th Ed.), Cambridge: Cambridge University Press, 2007.

${ }^{67}$ Andreosso-O'Callaghan Bernadette and Nicolas Françoise, "Complementarity and Rivalry in EU-China Economic Relations in the Twenty-First Century," European Foreign Affairs Review, Vol. 12, No. 1, 2007, p. 13.

68 The White House, A National Security Strategy of Engagement and Enlargement, Washington, DC: The White House, July 1994, <http://www. bits.de/NRANEU/others/strategy/nss94.pdf> 